\title{
Editorial: Why affirmative critique?
}

Having completed my Master's study on power in the classroom, I had a tremendous feeling: I had discovered so much. The ethnographic research had been eye-opening. Everything related to my Foucault-inspired notion of power and discourse - how thoroughly embedded we were in power structures and webs of power relations. I saw and realized now things that others hardly noticed within the business-as-usual. For example, the teacher of my research class was obvious to how she was reinforcing discourses of normalised gender within the seemingly innocent everyday practices of school. I felt uneasy about talking to the teacher about what I had noticed. I was afraid that it could hurt her feelings, make her feel negative about herself as teacher. I still don't know whether she read my study. I also struggled to find ways of talking about my study with the pupils of the class, about the games that the girls enjoyed, the ways in which they learned to be disciplined as they lived their everyday lives. I did feel the urge to inform them about the critical aspects I had discovered - that all their actions reflected power and even if they did not know it themselves, they were constantly reproducing restricting discourses.

The auditorium is full of people. Here we are, educational scholars at an international conference. The keynote speaker presents an ongoing research project. It concerns schooling, gender and racism. The PowerPoint slide gives an example of how student's racist comments are met with silence from the teachers. We read how the teacher ignores and diminishes other students' attempts to raise these issues. The response from the auditorium is laughter-of surprise for the teachers' way of acting? at how foolish the teacher appears when ignoring the students' questions? how absurd the situation seems? The analysis dismantles the teachers' difficulties with handling the racist comments from students. And there it ends. I leave the auditorium sad and angry. What had this critical analysis been part of producing? Retelling the story of incompetent teachers, not fulfilling their obligations. Is that the story we want to tell?

We begin this special issue by relating to two affective events situated in academia and education. These moments, and many similar, have stayed with us and kept us thinking about what kind of research we want to advance. These moments are laden with ambivalence. On the one hand, there was the joy of learning about power: being able to distract what was "behind" the everyday practices we had grown used to. After all, it was our uncompromised responsibility as researchers to uncover processes of oppression and discrimination. On the other hand, there were disturbing feelings as this kind of critical research seemed to drive both research subjects and researcher into positions that failed to connect: positions that did not facilitate dialogue or the creation of something different. For us, the main question arising was: how might we investigate pressing problems such as racial or gender discrimination while fostering the opportunity to make a difference? How can we raise these issues while at the same time creating possibilities for movement and change?

The five articles that form this special issue work with the ambivalences, difficulties and tensions of critical research in education by turning to an affirmative critical stance. This emerging way of 
approaching criticality is perhaps most strongly associated with the philosopher Rosi Braidotti (2010a; 2010c) and her elaboration of positive difference inspired by Gilles Deleuze (2001). The need to tackle the problematic relationship between the "knowing" researcher and the "known" participants, such as those exemplified above, is not a new discovery, rather, it has been widely recognized by feminist researchers for some time. For example, the works of Patti Lather (2001) and Wanda Pillow (2003) attended to the power relations formed in research, raising questions about representation and reflexivity. These discussions have taken new turns in the theoretical landscape of new empiricisms (feminist new materialisms, sociomaterialism or posthumanist theories), which stress that agencies are produced in networks or assemblages that are more-than-human. At the heart of these approaches, the modernist researcher subject begins to unfold (see St. Pierre, 2011). This destabilizes any previous notions of reflexivity and representation and forces a rethinking of research methodologies tending towards the open-ended heterogeneity and relationality of material and embodied situations and practices. These new methodologies have to set aside the imaginary modernist subject - a subject that is singular, knowable, and fixable. Moreover, they need to challenge separations between "knowns, knowers and knowledge" (Verran, 2014, p. 529).

We are not alone in our pursuit for alternative, more affirmative modes of critical research. In addition to Braidotti and Deleuze, our main theoretical starting points come from philosophers Donna Haraway (2004), Bruno Latour (1993; 2004), Isabelle Stengers (2008) and Annemarie Mol (2010). We find resonance to our uneasy feelings in the term intoxicating power of critical research raised by Isabelle Stengers $(2008,42)$. Together with Maggie MacLure (2013) we question the usefulness of the analytical practices of exposing, explaining and unmasking in the name of critical research. We follow Bruno Latour's (2004) view that it is necessary to realize the limits of conventional structure-based criticality, which he sees as a kind of play enacted from morally comfortable places by those who master the right language and are able to point to things that are wrong. We find examples by Hillevi Lenz Taguchi and Anna Palmer (2013) concerning how to empirically and critically employ the ideas of diffraction and positive difference. When elaborating on 'concept as method', Lenz Taguchi (2017) urges us to experiment with concepts to invent methodologies that exceed conventional ways of producing knowledge and that afford differentiation. New kinds of methodological politics have been brought up by Richard Edwards and Tara Fenwick (2015) as they invite us to raise questions about how materialaffective assemblages produce both stabilization and movement in analyses that seek to "trace lines of possibilities" (ibid, p. 18). Furthermore, Dorthe Staunæs (2016) shows us how an affirmative critical stance simultaneously raises concerns and hopes for the future.

Why do we need to rethink criticality? Our belief is that the complex questions of our time cannot be answered by solely relying on clear divisions. The long-lasting Cartesian cogito constructed humans as ontologically other and superior to non-humans and enabled the belief that they, thanks to rationality, can make sense of nature by measuring and classifying it from distance. In connection with the complexities of digitalization, the advances in biopolitics, the unpredictability of global political economy, as well as the related global environmental challenges, these kinds of research strategies have become inadequate (e.g. Alaimo and Hekman 2008). The global warming of our planet has existential implications which affect our fundamental beliefs, the ontological assumptions underlying our everyday life. New kinds of ethical and political concerns have emerged (see Taylor et al. 2013). The questioning of what we thought of as the human center of the world and the destabilization of notions of space and time also necessitate shifts in what we wish to achieve as researchers. For us, it seems that these "ethico-onto-epistemological" (Barad, 2007, p. 185) concerns are especially pressing within education, as this domain is, or should be, dedicated to fostering the best possible potentials for livable futures on our planet. Any critical research on education should be re-estimated in the light of the necessity to 
understand both the material and discursive conditions of the world and the vital consequences of research.

When Bruno Latour stated in his 2004 article that critique has run out of steam, he invoked an association with energy. For us, the energy of conventional critical research, once stemming from political agendas of emancipation and identity, is likely to become suffocated in a dead end of conflicting and colonizing academic maneuvers. By affirmative critique we do not mean that the difficult questions can be left aside: it is not about looking at the bright side, staying positive and ignoring things that are wrong or problematic. There is no innocent escape from the colonizing foundations and effects of academic work as Haraway (e.g. 1997) reminds us. The affirmative difference lies in what we want to attend to and what we want to achieve. Perhaps the most important question is, will the critique be able to change the things we critique? If we explain what is wrong and what lies behind, can we exceed what we already know? And what becomes into existence as a result of these critiques? We see a possibility of rediscovering energy in the realization that the future is fundamentally open. The future is built upon the knowledge we produce - that is why it is important to imagine and to experiment.

The research presented in this special issue is defined by its experimental and empirical approaches. In our various projects we want to elaborate how the theoretical premise of the 'becoming' and materialdiscursive nature of practices could shape critical inquiry, and test this within various educational contexts. In the articles, the reader is offered a series of post-qualitative (e.g. St. Pierre, 2011) research strategies. This, for us, means experimenting with research - thinking-with, joining, attaching and touching - in non-reductive ways, in order to trace associations, attachments, enactments and assemblages that are not solely human. We engage with practices, occasions, occurrences, sometimes small moves, avoiding "the position of judging observer" (Verran, 2014, p. 530), but acknowledging the messy and fluid co-becoming of researcher and practices. Through attending to various comingstogether of these assemblages, forces and affectivity, we urge for possible openings for change. Might these alternative research stories, different from those presented at the opening of this editorial, work differently, towards affirmative, careful and immanent critiques? It is our wish that these materially entangled stories could afford a new kind of energy to critical inquiry. How this could be carried out when doing educational empirical work will be further explored and elaborated in the articles of this issue.

This special issue comes from collaboration between researchers from three Nordic countries, Norway, Finland and Sweden. We have been brought together by our shared interest in methodology, ethics, materiality and affectivity, and an interest in examining and exploring these through empirical contexts. Discussions have continued over numerous conferences, workshops and shared symposia. Riikka Hohti, in her article, analyzes the affective entanglements of special needs politics and teacher professionalism. She revisits the events involving a particular girl, Siiri, and herself as her teacher, and experiments by using the narrative approach "Bag lady storytelling" by Haraway (2014) to engage with situated and material complexities of education in a potentially affirmative way. By engaging with a health promoting practice in education Karin Gunnarsson explores methodological and empirical encounters with care. To do that, Gunnarsson puts to work a careful critique connected to notions of translation and touch. This research apparatus opens up the possibility to engage with the tensions and movements taking place within the practice and to explore how desire and power dance together. Emilie Moberg elaborates on alternative versions of critique as produced in an ethnographic study on the everyday life of a curriculum text in a Stockholm preschool. Using Actor-network theory and Feminist New Materialist methodologies as resources, her paper outlines an affirmative critique where dependency and vulnerability become resources in the researcher's strivings to find more ways in which entities in practices relate and overlap. This makes research into a relational achievement where the researcher inevitably needs to rely on and 
is afforded to act by children, Minecraft figures, concepts, teachers and conversations over coffee. Hanna Guttorm, as an autoethnographer, writes affirmatively with the new move in her life: starting to work with and in her Indigenous culture in Sámi University of Applied Sciences. She writes softly both with her memories and current experiences in order to build bridges and spaces for multiple Sáminesses. Camilla Eline Andersen draws from a recent study on professionalism and race in early childhood education to elaborate on what affirmative critique might be, and how this might be performed. in educational research. Her interested here concerns how to experiment analytically, and she presents a record of a process she calls art-ing. Working from an ontology of difference her suggestion is that the logic in predominant way of undertaking critique is not productive enough, and that 'methodological movement' (Koro-Ljungberg, 2012) might be a more generative approach. In the article, Andersen experiments with art-ing from a documentation of race-things to avoid an oppositional human centred critical approach and to flee a humanist making up of better solutions to the problem of race.

Within this gathering we have a shared ambition to set in motion some experimental and empirical engagements with theoretical insights that we find important and timely. In so doing, we want to create affective and political energy, which could be felt as wonder, anxiety, joy, or sadness, for example. Furthermore, we would like to handle affectivity with care, with "response-ability" (Barad, 2012) and turn it into questions and co-thinking.

For this co-operation we, the editors of this issue, are truly grateful. We would also like to express our gratitude to all our external reviewers, who have joined us with invaluable insights. One of the provocations passed to us from our reviewers was to cherish the variation of English language throughout the articles, as all the authors come from non-English speaking countries. To work and publish in "minoritarian" English in the dominantly Anglo-Saxon research community can be seen as a political act - an exciting one, and certainly not possible without collegial support. Last, our warmest thanks to the RERM editorial team, Jayne Osgood and Ann Merete Otterstad, whose support has made this special issue possible.

Finally, we frame this special issue on affirmative critique with a quote from Braidotti who asks "why should one pursue this project?" Her answer is sharp and provocative: "For no reason at all. Reason has nothing to do with this. Let's just do it for the hell of it and for love of the world" (2010b, p. 217).

Karin Gunnarsson karin.gunnarsson@hsd.su.se

Stockholm University

Riikka Hohti riikka.hohti@gmail.com

University of Oulu

\section{References}

Barad, K. (2007). Meeting the universe halfway: quantum physics and the entanglement of matter and meaning. Durham, N.C.: Duke University Press. https://doi.org/10.1215/9780822388128

Barad, K. (2012). On touching - The inhuman that therefore I am. differences, 23(3), 206-223. https://doi.org/10.1215/10407391-1892943 
Braidotti, R. (2010a). Nomadism: against methodological nationalism. Policy Futures in Education, 8(3-4), 408-418. https://doi.org/10.2304/pfie.2010.8.3.408

Braidotti, R. (2010b). The politics of "life itself" and new ways of dying. Coole, D.H. \& Frost, S. (eds.) New materialisms: ontology, agency, and politics. Durham, N.C.: Duke University Press.

Braidotti, R. (2010c). On putting the active back into activism. New Formations, 68(68), 42-57. https://doi.org/10.3898/newf.68.03.2009

Deleuze, G. (2001). Difference and Repetition. (P. Patton, Trans., original 1968.). Continuum, London and New York.

Edwards, R. \& Fenwick, T. (2015). Critique and Politics: A sociomaterialist intervention, Educational Philosophy and Theory, 47(13-14), 1385-1404. https://doi.org/10.1080/00131857.2014.930681

Haraway, D. (1997).Modest_Witness@Second_Millennium.FemaleMan (C_Meets_OncoMouse ${ }^{\text {TM }}$ London and New York: Routledge.

Haraway, D. (2004). The Haraway reader. Routledge, New York \& London.

Koro-Ljungberg, M. (2012). Researchers of the world, create!. Qualitative inquiry, 18(9), 808-818. https://doi.org/10.1177/1077800412453014

Lather, P. (2001). Postbook: Working the ruins of feminist ethnography. Signs: Journal of women in culture and society, 27(1), 199-227. https://doi.org/10.1086/495677

Latour, B. (2004). Why Has Critique Run out of Steam? From Matters of Fact to Matters of Concern. Critical Inquiry, 30(2), 225-248. https://doi.org/10.1086/421123

Latour, B. (1993). We have never been modern. Translated by C. Porter. Harvester Wheatsheaf, New York.

Lenz Taguchi, H. (2017). "This Is Not a Photograph of a Fetus": A feminist reconfiguration of the concept of posthumanism as the ultrasoundfetusimage. Qualitative Inquiry, 23(9), 699-710.

https://doi.org/10.1177/1077800417732644

Lenz Taguchi, H. \& Palmer, A. (2013). A more 'livable' school? A diffractive analysis of the performative enactments of girls' ill-/well-being with(in) school environments. Gender and Education 25(6), 671-687. https://doi.org/10.1080/09540253.2013.829909

Mol, A. (2010). Actor-network theory: Sensitive terms and enduring tensions. Kölner Zeitschrift für Soziologie und Sozialpsychologie. Sonderheft, 50, 253-269.

Pillow, W. (2003). Confession, catharsis, or cure? Rethinking the uses of reflexivity as methodological power in qualitative research. International journal of qualitative studies in education, 16(2), 175-196. https://doi.org/10.1080/0951839032000060635

Staunæs, D. (2016). Notes on inventive methodologies and affirmative critiques of an affective edufuture. Research in Education, 96(1), 62-70. https://doi.org/10.1177/0034523716664580

Stengers, I. (2008). Experimenting with refrains: subjectivity and the challenge of escaping modern dualism. Subjectivity, 22, 38-59. https://doi.org/10.1057/sub.2008.6

St. Pierre, E. A. (2011). Post qualitative research: The critique and the coming after. In Denzin, N.K. \& Lincoln, Y.S. (eds.). The Sage handbook of qualitative research, 4, 611-626. Sage, Thousand Oaks, CA.

Taylor, A. Blaise, M. \& Giugni, M. (2013). Haraway's 'bag lady story-telling': relocating childhood and learning within a 'post-human landscape'. Discourse: Studies in the Cultural Politics of Education, 34(1), 48 -62. https://doi.org/10.1080/01596306.2012.698863

Verran, H. (2014). Working with those who think otherwise. Common Knowledge, 20(3), 527-539. https://doi.org/10.1215/0961754X-2733075 